\title{
Safety Profile, Feasibility and Early Clinical Outcome of Cotransplantation of Olfactory Mucosa and Bone Marrow Stem Cells in Chronic Spinal Cord Injury Patients
}

\author{
Vijay G Goni ${ }^{1}$, Rajesh Chhabra ${ }^{2}$, Ashok Gupta ${ }^{3}$, Neelam Marwaha ${ }^{4}$, Mandeep S Dhillon ${ }^{5}$, \\ Sudesh Pebam ${ }^{5}$, Nirmal Raj Gopinathan ${ }^{5}$, Shashidhar Bangalore Kantharajanna ${ }^{6}$ \\ ${ }^{1}$ Department of Orthopaedic Surgery, Post Graduate Institute of Medical Education and Research, Chandigarh, India \\ ${ }^{2}$ Department of Neurosurgery, Post Graduate Institute of Medical Education and Research, Chandigarh, India \\ ${ }^{3}$ Department of Otolaryngology, Post Graduate Institute of Medical Education and Research, Chandigarh, India \\ ${ }^{4}$ Department of Transfusion Medicine, Post Graduate Institute of Medical Education and Research, Chandigarh, India \\ ${ }^{5}$ Department of Orthopaedic Surgery, Post Graduate Institute of Medical Education and Research, Chandigarh, India \\ ${ }^{6}$ SBK Spine Clinic, Bangalore, India
}

\section{Study Design: Prospective case series.}

Purpose: To study the safety and feasibility of cotransplantation of bone marrow stem cells and autologous olfactory mucosa in chronic spinal cord injury.

Overview of Literature: Stem cell therapies are a novel method in the attempt to restitute heavily damaged tissues. We discuss our experience with this modality in postspinal cord injury paraplegics.

Methods: The study includes 9 dorsal spine injury patients with American Spinal Injury Association (ASIA) Impairment Scale (AIS) A neurological impairment who underwent de-tethering of the spinal cord followed by cotransplantation with bone marrow stem cells and an olfactory mucosal graft. Participants were evaluated at the baseline and at 6 monthly intervals. Safety and tolerability were evaluated through the monitoring for adverse events and magnetic resonance imaging evaluation. Efficacy assessment was done through neurological and functional outcome measures.

Results: Surgery was tolerated well by all participants. No significant difference in the ASIA score was observed, although differences in the Functional Independence Measure and Modified Ashworth Scale were statistically significant. No significant complication was observed in any of our patients, except for neurogenic pain in one participant. The follow-up magnetic resonance imaging evaluation revealed an increase in the length of myelomalacia in seven participants.

Conclusions: The cotransplantation of bone marrow stem cells and olfactory mucosa is a safe, feasible and viable procedure in AIS A participants with thoracic level injuries, as assessed at the 24-month follow-up. No efficacy could be demonstrated. For application, further large-scale multicenter studies are needed.

Keywords: Thorax; Spinal cord regeneration; Stem cells

Received Jul 15, 2013; Revised Sep 6, 2013; Accepted Sep 15, 2013

Corresponding author: Shashidhar Bangalore Kantharajanna

SBK Spine Clinic, 286, 7th A Main, 3rd Bloc, 1st Stage, HBR Layout, Bangalore 560043, India

Tel: +91-9845529706, Fax: +91-172-2721133, E-mail: drshashidharbk@gmail.com 


\section{Introduction}

The term "tissue engineering," as described by Langer and Vacanti [1], connotes an interdisciplinary field, which conflates the concepts of life sciences and engineering with the objective of developing biological substitutes that may facilitate the regeneration of tissues or revivification of biomimetic functions. Regenerative medicine has been acknowledged as the most feted ramus of the medical discipline, primarily on account of the miraculous potentials envisaged by its proponents [2]. With such an enormous capability anticipated, scientists worldwide have optatively proposed its usefulness in innumerable abject and desperate situations. Circumstances that may endorse the employment of these sophisticated management alternatives include spinal cord injury with neurological disability, where the conventional modalities of intervention involve an observant "wait and watch approach" $[3,4]$. These injuries so gravely incapacitate the victims that even recovery involving a single level of cord segment may improve the quality of living by a staggering magnitude.

The present article condenses our experience with cellbased therapy involving cotransplantation of autologous bone marrow and olfactory mucosal stem cells into the spinal cord in neurologically disabled spinal injury patients and discusses the safety, feasibility and the early clinical outcome of the procedure. To our knowledge, ours is the first such prospective human trial conducted in posttraumatic neurologically impaired individuals.

\section{Materials and Methods}

The study was approved by the Institutional Ethics Committee and Institutional Committee on Stem Cell Research and Therapy in a meeting headed by the director of the Indian Council of Medical Research, Government of India. We certify that all applicable institutional and governmental regulations concerning the ethical use of human volunteers were followed during the course of this research. The study design was in conformance with the 'Guidelines for the conduct of clinical trials for spinal cord injury' as developed by the International Campaign for Cures of Spinal Cord Injury Paralysis panel [5]. The patients were recruited into the study after giving written informed consent. The possible complications of the procedure were explained to the patient, including the loss of olfaction, variable loss of sensory or motor functions, meningitis, wound infection and neuropathic pain.

The present study included 9 spinal cord injury patients brought to our outpatient services between January 2010 and June 2011. Only patients aged between 18 and 55 years, who had sustained the injury at least 6 months earlier, with a fracture level between T1 and T12 vertebral segments, with an American Spinal Injury Association (ASIA) [6,7] impairment scale of A, and the length of spinal cord lesion as revealed on the magnetic resonance imaging (MRI) as being less than $6 \mathrm{~cm}$ were included in our study. Those with inoperable nasal lesions, severe medical illnesses or prior participation in cellular transplantation trials were excluded.

A nasal swab was obtained in all patients and cultures for bacterial and/or fungal contamination were carried out preoperatively. The procedure was performed only in patients who demonstrated a sterile culture with or sans the appropriate antibiotic therapy.

\section{Procedure}

Under adequate local anesthesia, approximately 50 to 100 $\mathrm{mL}$ of bone marrow was aspirated from one/both iliac crests and stem cells were isolated as per the conventional technique [8-10]. The human surgical procedure of cotransplantation was performed according to the technique developed by Lima et al. [11]. The head and neck surgeon harvested the olfactory mucosal graft through a transnasal endoscopic approach with the patient in the supine position (prone position in participant 1). The injured part of the spinal cord was exposed using a standard posterior approach. 'De-tethering' of the injured cord was performed using a standard surgical microscope, with the removal of any adhesions. Scars at the lesion site were removed to expose the residual spinal tissue on both sides, leaving a cavity in the spinal cord at the site of the injury. After rinsing in saline, the mucosal graft was cut into small pieces and transplanted along with the bone marrow stem cells into the previously prepared spinal cord cavity at the site of the injury (Figs. 1-3). A sample of the olfactory mucosa harvested during the surgery was sent for histological and microbiological examination.

Participants were discharged from the hospital as soon as they recuperated up to their preoperative state. All participants followed a standardized physical rehabilitation program with a follow-up assessment at 6 months 
that included an MRI (to look for infection, hemorrhage, cyst/syrinx, tumor and increase in myelomalacia).

The safety and tolerability of the procedure were evaluated through the monitoring of:

- Donor site related adverse events such as decreased functional olfaction, healing problems.

- Recipient site adverse events such as any sign of aseptic/septic meningitis, rejection of the graft, and neuropathic pain.

- Intraoperative and postoperative vital signs and systemic laboratory examinations.

- Viral, fungal and aerobic cultures of the transplanted tissue.

- Aggravation of the neurological deficit or pain.

- Systemic complications.

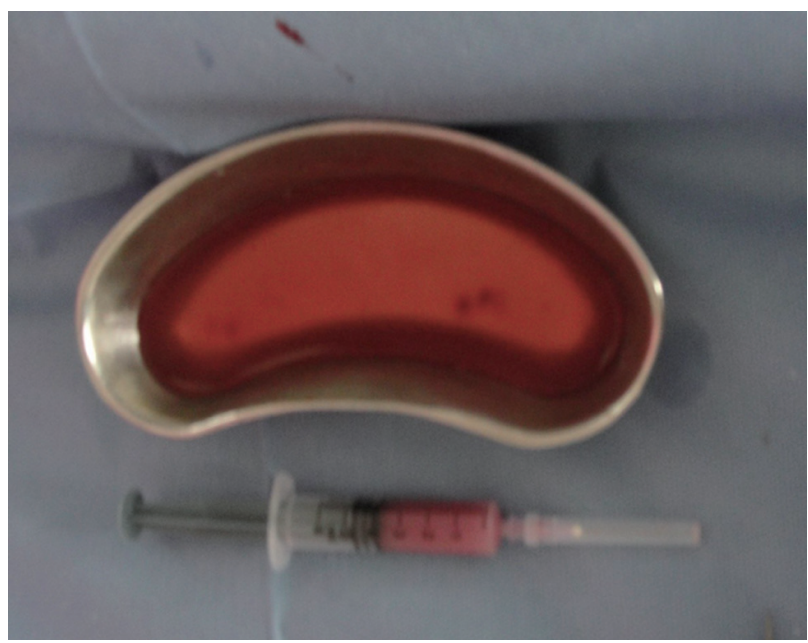

Fig. 1. Harvested olfactory mucosa and bone marrow stem cells.

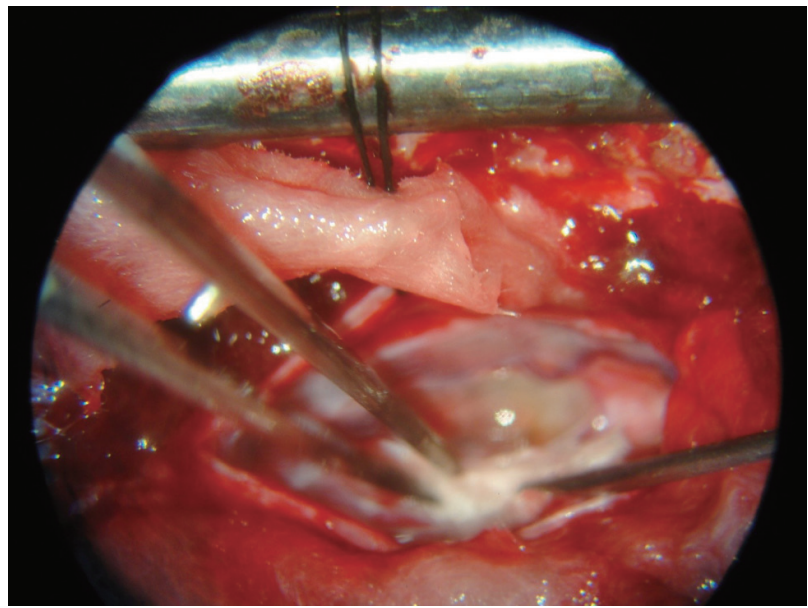

Fig. 2. Transplantation of olfactory mucosal tissue into the space created.
The primary efficacy end point was defined as the improvement in the clinical status of the patient according to the ASIA score [6], while the secondary efficacy endpoints included the Functional Independence measure [7] and the Modified Ashworth Score.

\section{Results}

The mean age of the study group was 30.3 years and the study group included only one female. The mean duration at admission since the spinal injury was 21 months, and 8 patients had previous surgery for the fracture.

The preoperative nasal swab was positive for Staphylococcus aureus in 2 patients. These patients were treated with a local application of $2 \%$ mupirocin and were only taken up for surgery when the nasal swab became negative. One patient had an injury involving the $\mathrm{T} 5$ vertebra, 2 had sustained a T8 fracture, 3 subjects had an injury at T10 and 3 patients had a thoracic vertebral fracture.

\section{Efficacy indicators}

The mean length of myelomalacia before surgery was 3.27 , which changed to 3.45 at the final follow-up at 24

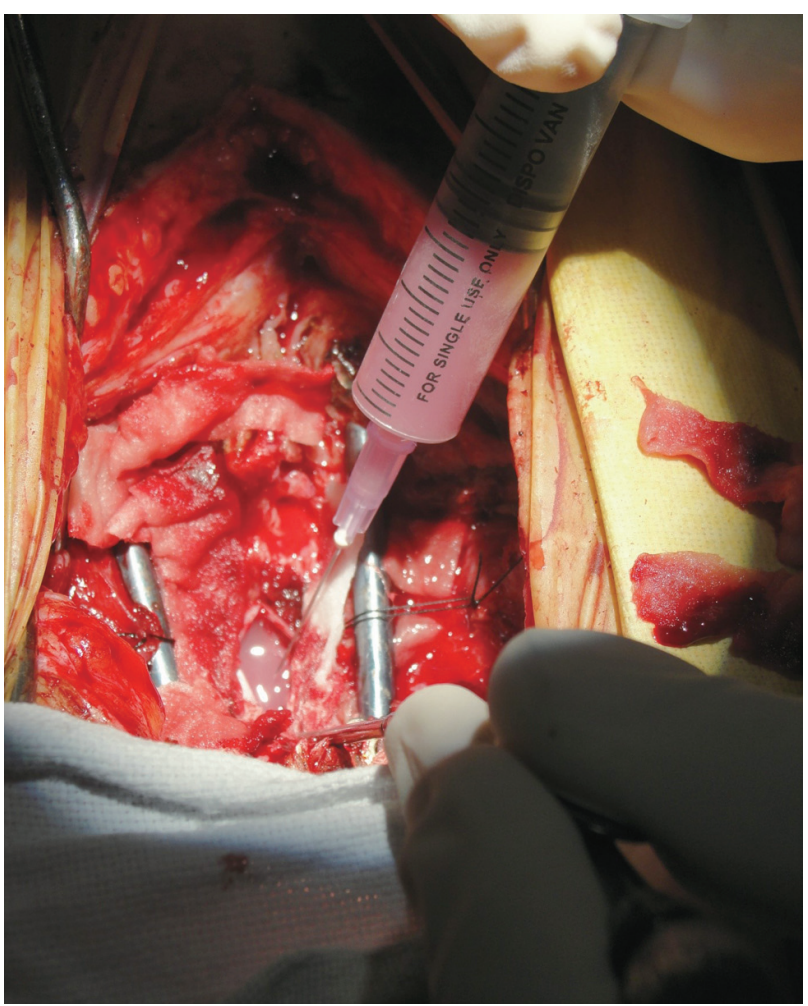

Fig. 3. Injection of bone marrow stem cells into the space created. 
Table 1. General outcome variables as observed preoperatively and 6 months postoperatively

\begin{tabular}{|c|c|c|c|c|c|c|c|c|c|c|c|c|}
\hline \multirow{2}{*}{$\begin{array}{c}\text { Sample } \\
\text { no. }\end{array}$} & \multicolumn{2}{|c|}{ Myelomalacia } & \multicolumn{2}{|c|}{ ASIA motor } & \multicolumn{2}{|c|}{ ASIA light touch } & \multicolumn{2}{|c|}{ ASIA pinprick } & \multicolumn{2}{|c|}{ FIM score } & \multicolumn{2}{|c|}{$\begin{array}{c}\text { Modified } \\
\text { Ashworth score }\end{array}$} \\
\hline & 0 mo & $6 \mathrm{mo}$ & $0 \mathrm{mo}$ & $6 \mathrm{mo}$ & $0 \mathrm{mo}$ & $6 \mathrm{mo}$ & $0 \mathrm{mo}$ & $6 \mathrm{mo}$ & $0 \mathrm{mo}$ & $6 \mathrm{mo}$ & $0 \mathrm{mo}$ & $6 \mathrm{mo}$ \\
\hline 1 & 3.4 & 3.6 & 50 & 50 & 72 & 72 & 72 & 72 & 110 & 116 & 2 & 0 \\
\hline 2 & 2.8 & 2.8 & 50 & 50 & 72 & 72 & 72 & 72 & 112 & 118 & 3 & 0 \\
\hline 3 & 3.2 & 3.5 & 50 & 50 & 64 & 64 & 64 & 64 & 114 & 117 & 3 & $1+$ \\
\hline 4 & 3 & 3.2 & 50 & 50 & 56 & 56 & 56 & 56 & 106 & 114 & 2 & 2 \\
\hline 5 & 2.6 & 3.0 & 50 & 50 & 64 & 64 & 64 & 64 & 113 & 117 & 2 & 0 \\
\hline 6 & 2.8 & 2.8 & 50 & 50 & 72 & 72 & 72 & 72 & 116 & 118 & 1 & 2 \\
\hline 7 & 3.8 & 4.1 & 50 & 50 & 68 & 68 & 68 & 68 & 110 & 116 & 2 & $1+$ \\
\hline 8 & 4.1 & 4.1 & 50 & 50 & 56 & 56 & 56 & 56 & 104 & 118 & 3 & 2 \\
\hline 9 & 3.8 & 4.0 & 50 & 50 & 44 & 44 & 44 & 44 & 100 & 115 & 1 & $1+$ \\
\hline
\end{tabular}

ASIA, American Spinal Injury Association; FIM, Functional Independence Measure.

months. No change was observed in the ASIA motor and sensory scores in any of the participants. The mean Functional Independence Measure Scores before and after surgery were 110.55 and 116.55 , respectively. These differences were statistically significant (Wilcoxon signed rank test). But this was more due to the rehabilitation protocol of physiotherapy, and bowel and bladder and self care than due to motor or sensory recovery. The mean muscle tone score preoperatively and postoperatively as measured by the Modified Ashworth Score were 2.11 and 1.00, respectively. The difference reached statistical significance at a $p$-value of 0.04 (Wilcoxon signed ranked test). This was again attributed to surgical de-tethering and the supplementary rehabilitative and physiotherapy protocol.

The general outcome variables in our patients have been tabulated below (Table 1).

The intraoperative olfactory sample sent for pathological examination showed olfactory mucosal tissue in 8 participants. A negative biopsy was seen in one patient in whom the prone position was used for the harvesting and in another patient in whom the olfactory mucosa was probably replaced by respiratory tissue as occurs with old age. Culture and sensitivity of the olfactory harvest was positive in 1 case for methicilin resistant Staphylococcus aureus. But the patient had no perioperative complications.

The mean volume of the aspirate from the iliac crest, the mean mononuclear cell count, the cluster of differentiation 35 count and the mean viable cell count were $113.60 \mathrm{~mL}, 2.99,1.13$, and 94.10 , respectively. The average hospital stay was 7 days.

\section{Complications}

There were no donor site related adverse events associated with the harvesting of the stem cells. None of the patients showed any change in olfaction or had donor site healing problems or septic/aseptic meningitis or other serious infections. Postoperative, temporary neuropathic pain was seen in 2 patients.

\section{Discussion}

It is generally conceived that the mechanism of spinal cord damage includes four major morphological patterns: cord maceration, cord laceration, contusion and solid cord injury [12]. The first two injuries are more likely to be irreversible with laceration of the cord surface and a prominent, resultant connective tissue response.

The three phases of cord response following an injury to the spine include acute, secondary, and chronic injury processes [13]. In the acute phase, direct mechanical damage to neural and soft tissues results in necrosis, or cell death. This is followed by the secondary phase, where the ischemic cytonecrosis conduces to cellular lysis with resultant exponentiation of lipid peroxidation and inflammatory mediator synthesis, which further commove the pericellular homeostatic equilibrium. Finally, in the chronic phase, diverse responses including apoptosis, scarring, tethering, cyst formation, regeneration and 
Table 2. Literature review on attempts at stem cell therapy in spinal cord repair

\begin{tabular}{|c|c|c|c|c|c|}
\hline $\begin{array}{l}\text { Sample } \\
\text { No. }\end{array}$ & Study & Patient profile & $\begin{array}{l}\text { Inclusion } \\
\text { criteria }\end{array}$ & Efficacy assessment & Complications \\
\hline 1 & $\begin{array}{l}\text { Lima et al. [11]; olfactory } \\
\text { mucosal grafts }\end{array}$ & $\begin{array}{l}7 \text { Patients (6 mo- } \\
6.5 \text { yr postinjury) }\end{array}$ & $\begin{array}{l}\text { ASIA A or B } \\
\text { Less than } \\
35 \mathrm{yr}\end{array}$ & $\begin{array}{l}\text { ASIA sensory and motor gains } \rightarrow \\
\text { statistically significant }\end{array}$ & $\begin{array}{l}\text { Temporary loss of olfaction } \\
\rightarrow \text { many patients } \\
2 \text { Patients-temporary pain }\end{array}$ \\
\hline 2 & $\begin{array}{l}\text { Mackay-Sim et al. [14]; } \\
\text { olfactory ensheathing } \\
\text { cells }\end{array}$ & 6 Patients & $\begin{array}{l}\text { Complete, } \\
\text { thoracic } \\
\text { paraplegia }\end{array}$ & $\begin{array}{l}\text { 3-yr follow-up } \\
\text { No improvement on MRI } \\
\text { No functional improvement }\end{array}$ & Safe-3 yr follow-up \\
\hline 3 & $\begin{array}{l}\text { Rabinovich et al. [15]; } \\
\text { fetal haematopoietic } \\
\text { neural stem cells and } \\
\text { olfactory ensheathing } \\
\text { cells }\end{array}$ & $\begin{array}{l}15 \text { Patients } \\
\text { (1 mo-6 yr } \\
\text { postinjury) }\end{array}$ & $\begin{array}{l}\text { Incomplete } \\
\text { injury } \\
18-52 \text { yr }\end{array}$ & $\begin{array}{l}1.5-3 \text { yr follow-up } \\
\text { Noticeable clinical improvement } \\
\text { in } 11 \text { out of } 15 \text { patients } \\
\text { Frankel } A \text { to } C \text { ( } 5 \text { patients) } \\
\text { Frankel A to } B / C \text { ( } 3 \text { patients) }\end{array}$ & - \\
\hline 4 & $\begin{array}{l}\text { Chhabra et al. [16]; } \\
\text { olfactory mucosal } \\
\text { grafts }\end{array}$ & 5 Patients & $\begin{array}{l}\text { Chronic, motor } \\
\text { complete } \\
\text { injury } \\
\text { C5-T12 }\end{array}$ & $\begin{array}{l}\text { No significant improvement- } \\
\text { neurological, electrophysiological } \\
\text { or urodynamic efficacy variables } \\
\text { Statistically significant } \\
\text { improvement-in functional } \\
\text { scores }\end{array}$ & $\begin{array}{l}\text { Syrinx (1 patient) } \\
\text { Increase in length of } \\
\text { myelomalacia } \\
\text { (4 patients) }\end{array}$ \\
\hline 5 & $\begin{array}{l}\text { Sykova et al. [9]; marrow } \\
\text { stromal cells injected } \\
\text { intravenously }\end{array}$ & $\begin{array}{l}9 \text { Patients } \\
\text { (21-41 yr) }\end{array}$ & $\begin{array}{l}\mathrm{Th}_{9} \text { (2 patients); } \\
\mathrm{C}_{4} \text { to } \mathrm{C}_{7} \\
\text { (remaining) }\end{array}$ & $\begin{array}{l}\text { Some improvement seen } \\
\text { (6 patients) } \\
\mathrm{C}_{6} \text { fracture-ASIA B to D (1 patient) }\end{array}$ & No adverse events \\
\hline 6 & $\begin{array}{l}\text { Moviglia et al. [10]; } \\
\text { bone-marrow stem cells } \\
\text { and autologous } \\
\text { auto-immune T-cells }\end{array}$ & 8 Patients & - & ASIA A to D (5 patients) & - \\
\hline 7 & $\begin{array}{l}\text { Deng et al. [8]; bone } \\
\text { marrow stromal cells and } \\
\text { olfactory ensheathing } \\
\text { cells }\end{array}$ & $\begin{array}{l}\text { Thoracic spinal } \\
\text { cord injury in a } \\
\text { rat model }\end{array}$ & - & $\begin{array}{l}\text { Synergistic amelioration of spinal } \\
\text { cord injury }\end{array}$ & - \\
\hline
\end{tabular}

ASIA, American Spinal Injury Association; MRI, magnetic resonance imaging.

sprouting ensue.

Research on stem cells is gradually evolving to the point where stem cells are considered as the philosopher's stone that may render a solution to some of the mystifying puzzles faced by the present-day medical fraternity. Various researchers have trialed this "wonder seed" of the biological cosmos in an attempt to restore neurological functioning in paraplegics [8-11,14-17]. Stem cells may achieve spinal cord repair by one of the following processes [18]: 1) By acting as a cellular bridge, 2) By providing a source of new neurons or, 3 ) By secreting neurotropic substances which promote repair.

Although several components of the olfactory mucosa may contribute to its effective regenerating abilities, two cell types that are especially believed to enhance the repair of the nervous system are stem-like progenitor cells and olfactory ensheathing cells [19-21]. Removing a part of the olfactory mucosa does not permanently damage olfaction on account of its continuous regenerating capability.

Several human studies have used autologous olfactory unsheathing cells [11,14-16] and bone marrow stoma cells $[9,22,23]$ to promote spinal cord repair. Combined cellular strategies for spinal cord injury have also been evaluated in animal $[8,24,25]$ and human [10] studies. A brief literature review regarding the use of stem cells in cord injury has been tabulated below (Table 2).

Harvesting of the olfactory mucosal transplant is more technically demanding than harvesting of standardized bone marrow stem cells from the iliac crest [11]. The histopathology of a sample from the harvested material in the lone participant in whom the harvest was carried out with the patient in the prone position suggested that it was predominantly respiratory mucosa. In all the other participants, the harvesting was done with the patient in the supine position as the operating surgeon found it 
more comfortable.

In our study, the scar was surgically removed guardedly and circumspectly to ensure continuity between the graft and normal cord tissue. Only ASIA Impairment Scale (AIS) A and dorsal spine fracture patients were included in our study as it was considered inappropriate to test the feasibility and safety aspects of a relatively naïve and untested procedure on more risky patients.

There was no significant improvement in the primary efficacy variables, and although the secondary efficacy variables showed a significant difference, they could not be attributed entirely to the stem cell therapy. These outcomes correspond to the natural history of complete spinal cord injury [13]. The procedure was generally tolerated well, and demurring, with MRI findings of an increase in the length of myelomalacia in seven participants. This might be imputed to the additional process of myelotomy or scar excision of the cord (which is considered a barely forgiving procedure in inexperienced hands).

Postoperative neuropathic pain was the only significant complication seen in two of our patients. In the pilot study by Lima et al. [11], one participant had loss of sensation, which according to the authors was due to the sensory axons getting damaged during the surgical procedure because of the difficulty of locating the site of the lesion. In the study by Chhabra et al. [16], loss of sensation immediately after surgery was seen in two participants and was reported to be a complication of the myelotomy and scar removal procedure. Even though one of the participants recovered almost full sensation, these findings suggest that the procedure should be done cautiously and only by very experienced surgeons. AIS B participants should preferably be excluded from such studies. We in our study have included only AIS A participants.

We acknowledge the following limitations of our study:

- A small sample size;

- Inability to estimate the exact number of transplanted cells;

- Relatively short follow-up;

- A specified rehabilitation protocol;

- Technically demanding surgery;

- Absence of a control group.

\section{Conclusions}

We could conclude that the procedure of spinal cord detethering followed by co-transplantation of bone marrow stem cells and olfactory nasal mucosa was a relatively safe and feasible procedure and the present scenario calls for further large-scale, randomized controlled prospective trials to establish the efficacy of this procedure which might potentially transmute the lives of innumerable unfortunate individuals.

\section{Conflict of Interest}

No potential conflict of interest relevant to this article was reported.

\section{Acknowledgments}

The study was part of the postgraduate thesis of author Shashidhar Bangalore Kantharajanna, at Post Graduate Institute of Medical Education and Research, Chandigarh, India

\section{References}

1. Langer R, Vacanti JP. Tissue engineering. Science 1993;260:920-6.

2. Chiu WT, Lin HC, Lam C, Chu SF, Chiang YH, Tsai SH. Review paper: epidemiology of traumatic spinal cord injury: comparisons between developed and developing countries. Asia Pac J Public Health 2010;22:9-18.

3. Spinal cord injury Facts and figures at a glance. J Spinal Cord Med 2008;31:357-8.

4. Ditunno JF Jr, Young W, Donovan WH, Creasey G. The international standards booklet for neurological and functional classification of spinal cord injury. American Spinal Injury Association. Paraplegia 1994;32:70-80.

5. Tuszynski MH, Steeves JD, Fawcett JW, et al. Guidelines for the conduct of clinical trials for spinal cord injury as developed by the ICCP Panel: clinical trial inclusion/exclusion criteria and ethics. Spinal Cord 2007;45:222-31.

6. Hamilton BB, Granger CV, Sherwin FS, et al. A uniform national data system for medical rehabilitation. In: Fuhrer MJ, editor. Rehabilitation outcomes: analysis and measurement. Baltimore, MD: Brookes; 1987. p.137-47.

7. Haas BM, Bergstrom E, Jamous A, Bennie A. The inter rater reliability of the original and of the modi- 
fied Ashworth scale for the assessment of spasticity in patients with spinal cord injury. Spinal Cord 1996;34:560-4.

8. Deng YB, Liu Y, Zhu WB, et al. The co-transplantation of human bone marrow stromal cells and embryo olfactory ensheathing cells as a new approach to treat spinal cord injury in a rat model. Cytotherapy 2008;10:551-64.

9. Sykova E, Homola A, Mazanec R, et al. Autologous bone marrow transplantation in patients with subacute and chronic spinal cord injury. Cell Transplant 2006;15:675-87.

10. Moviglia GA, Varela G, Brizuela JA, et al. Case report on the clinical results of a combined cellular therapy for chronic spinal cord injured patients. Spinal Cord 2009;47:499-503.

11. Lima C, Pratas-Vital J, Escada P, Hasse-Ferreira A, Capucho C, Peduzzi JD. Olfactory mucosa autografts in human spinal cord injury: a pilot clinical study. J Spinal Cord Med 2006;29:191-203.

12. Basso DM, Beattie MS, Bresnahan JC. Graded histological and locomotor outcomes after spinal cord contusion using the NYU weight-drop device versus transection. Exp Neurol 1996;139:244-56.

13. Tator $\mathrm{CH}$. Biology of neurological recovery and functional restoration after spinal cord injury. Neurosurgery 1998;42:696-707.

14. Mackay-Sim A, Feron F, Cochrane J, et al. Autologous olfactory ensheathing cell transplantation in human paraplegia: a 3-year clinical trial. Brain 2008;131:2376-86.

15. Rabinovich SS, Seledtsov VI, Poveschenko OV, et al. Transplantation treatment of spinal cord injury patients. Biomed Pharmacother 2003;57:428-33.

16. Chhabra HS, Lima C, Sachdeva S, et al. Autologous olfactory [corrected] mucosal transplant in chronic spinal cord injury: an Indian Pilot Study. Spinal Cord
2009;47:887-95.

17. Burns AS, Ditunno JF. Establishing prognosis and maximizing functional outcomes after spinal cord injury: a review of current and future directions in rehabilitation management. Spine (Phila Pa 1976) 2001;26(24 Suppl):S137-45.

18. Nandoe Tewarie RS, Hurtado A, Bartels RH, Grotenhuis A, Oudega M. Stem cell-based therapies for spinal cord injury. J Spinal Cord Med 2009;32:105-14.

19. Huard JM, Youngentob SL, Goldstein BJ, Luskin MB, Schwob JE. Adult olfactory epithelium contains multipotent progenitors that give rise to neurons and non-neural cells. J Comp Neurol 1998;400:469-86.

20. Roisen FJ, Klueber KM, Lu CL, et al. Adult human olfactory stem cells. Brain Res 2001;890:11-22.

21. Murrell W, Feron F, Wetzig A, et al. Multipotent stem cells from adult olfactory mucosa. Dev Dyn 2005;233:496-515.

22. Geffner LF, Santacruz P, Izurieta M, et al. Administration of autologous bone marrow stem cells into spinal cord injury patients via multiple routes is safe and improves their quality of life: comprehensive case studies. Cell Transplant 2008;17:1277-93.

23. Chernykh ER, Stupak VV, Muradov GM, et al. Application of autologous bone marrow stem cells in the therapy of spinal cord injury patients. Bull Exp Biol Med 2007;143:543-7.

24. Fouad K, Pearse DD, Tetzlaff W, Vavrek R. Transplantation and repair: combined cell implantation and chondroitinase delivery prevents deterioration of bladder function in rats with complete spinal cord injury. Spinal Cord 2009;47:727-32.

25. Zhang C, He X, Lan B, Li H. Study on repair of subacute spinal cord injury by transplantation of olfactory ensheathing cells combined with chondroitinase $\mathrm{ABC}$ in adult rats. Zhongguo Xiu Fu Chong Jian Wai Ke Za Zhi 2009;23:8-13. 